\title{
Human papillomavirus, integration and cervical carcinogenesis: a clinicopathological perspective
}

\author{
K Cooper, J O’D McGee
}

\begin{abstract}
Department of Anatomical Pathology, School of Pathology, South African Institute for Medical Research and University of Witwatersrand, Johannesburg, South Africa

K Cooper
\end{abstract}

Nuffield Department of Pathology, John Radcliffe Hospital, University of Oxford, Oxford

J O'D McGee

Correspondence to: Professor K Cooper, Department of Anatomical Pathology, SAIMR, PO Box 1038, Johannesburg 2000, South Africa.

Accepted for publication 17 December 1996
Cervical cancer is the second most common cancer globally. Four out of every five new cases of cervical cancer are diagnosed in developing countries worldwide. ${ }^{1}$ There is now sufficient evidence to suggest that the risk of developing cervical cancer is sexually transmitted. ${ }^{2}$ Epidemiological and experimental evidence suggests that human papillomavirus (HPV) is the infectious agent associated with cervical cancer. ${ }^{3}$ A recent survey of over 1000 specimens of cervical cancer from 22 countries confirmed conclusively that genital HPV is the main aetiological factor in cervical cancer worldwide. ${ }^{4}$ This study also demonstrated that more than 20 different genital HPV types are associated with cervical cancer from several countries.

A large study screening biopsy specimens from low/high grade squamous intraepithelial lesions and cervical cancers grouped different genital HPV types according to their prevalence. ${ }^{5}$ These groups were as follows: HPV 6, 11, 42, 43, and 44 as low risk types; HPV $31,33,35,51,52$, and 58 as intermediate risk types; and HPV 16, 18, 45, and 56 as high risk types. In the USA ${ }^{6}$ the prevalence of HPV DNA in definite cases of cervical intraepithelial neoplasia (CIN) approaches $100 \%$, with high risk HPV types accounting for over $50 \%$ of infections. The results of Koutsky et $a l^{7}$ support a direct progression of HPV infection to high grade CIN. These authors observed a high risk of rapid progression of HPV 16 or 18 cervical infection (cytologically negative) to high grade CIN in a cohort study. An independent cohort study from Finland ${ }^{8}$ arrived at similar conclusions, albeit over a longer period of time. A UK study examining a cohort of untreated patients with epithelial abnormalities of the cervix showed that detection of HPV 16 or 18 DNA sequences was associated with a significantly increased risk of disease progression. ${ }^{9}$ Hence, the type of HPV found in the cervix seems to predict the risk of progression to high grade cervical neoplasia. This association has been verified in both crosssectional and prospective studies. ${ }^{510}$

Recently, the role of HPV type specific persistent infection, especially in patients with a continual high viral load, has been associated with persistent cervical dysplasia. ${ }^{11}$ This pro- spective study focused on the determinants of persistence and progression versus regression of $\mathrm{CIN}$ in women with lesions diagnosed as CIN grade II. Repeated examinations over 15 months demonstrated persistent high levels of HPV detection (positive repeatedly by Southern blot) to be most predictive of CIN. ${ }^{11}$ In Sweden $^{12}$ the examination of archival Pap smears taken prior to the diagnosis of HPVcontaining cervical carcinoma has detected HPV DNA in the majority of smears preceding the cancer. Where preceding multiple smears were available, persistent HPV infection was demonstrated over a seven year period preceding the cancer diagnosis. ${ }^{12}$ A similar study from the Netherlands, assessing false negative archival Pap smears performed up to six years preceding the diagnosis of cervical cancer, demonstrated persistent HPV 16 or 18 in the majority of archival smears. ${ }^{13}$ These studies demonstrate that persistent HPV infection with a high risk type is strongly associated with cervical dysplasia and carries a greater risk of subsequent progression to cervical cancer. Furthermore, these studies indicate that the inclusion of HPV testing with cytological screening may help reduce the number of false negative smears. The mechanisms by which persistence of viral DNA within keratinocytes contributes to the process of cell transformation includes viral integration and extrachromosomal viral DNA replication. The latter involves a relation between viral gene expression, viral replication and cellular DNA replication pathways. ${ }^{14}$ In addition, if a high viral load does prove to be predictive of persistent cervical epithelial abnormalities, then the use of Hybrid Capture ${ }^{15}$ for HPV detection may be a useful system to quantify the amount of HPV DNA present in a sample.

It is widely accepted that HPV infection alone is not responsible for cervical neoplasia and that several co-factors have been identified. ${ }^{16}$ Although smoking, hormones and immune status are key co-factors in cervical carcinogenesis, none has been shown to predict the risk of progression to high grade cervical neoplasia. There is increasing evidence that the physical state of HPV within the nucleus of the host cell may play a major role in predicting the risk of progression of CIN. In fact, a pattern 
has emerged regarding the physical state of HPV DNA in CIN and squamous cell carcinoma (SCC) of the cervix ${ }^{17-19}$-episomes predominating in the early stages of CIN with integrated virus being detected more frequently in HPV positive, high grade CIN and SCC. The latter may or may not contain episomes as well. It has also been proposed that the physical state of HPV DNA may reflect a progression towards the malignant phenotype, ${ }^{2021}$ and that higher grade CIN lesions may originate from a single cell clone in which viral integration had occurred..$^{22} 23$ Hence, apart from CIN grade and HPV type being established risk factors in clinical progression, ${ }^{24}{ }^{25}$ there is strong evidence that the physical state of HPV DNA is also relevant.

These observations are strongly supported by in vitro experimental evidence regarding the interactions between viral transforming oncoproteins and host cell tumour suppressor gene proteins at a molecular/cellular level. ${ }^{26}$ It would seem that these events are dependent on integration of the viral genome into the host chromosome, resulting in the consistent disruption of the E2 gene $\mathrm{e}^{27}$ with the resultant loss of transactivating repressor effects on $\mathrm{E} 6 / \mathrm{E} 7$ genes. The effect thereof is overproduction of E6 and E7 protein, ${ }^{26}$ which transforms cells and confers immortality on the host cell. ${ }^{29}$ The E6 and E7 viral proteins have been shown to bind in vitro to host tumour suppressor gene products-p53 and Rb. ${ }^{30}{ }^{31}$ Tumour suppressor genes are responsible for the regulation of normal cell growth, and hence the demonstrated in vitro binding of their proteins with viral oncoproteins E6 and E7 has been proposed to result in loss of functional regulation of the cell growth control of the host cell. ${ }^{26}$ Hence the brakes on cell growth control are removed, resulting in dysregulation of the cell cycle. The importance of E6/p53 and E7/Rb binding is substantiated further as their ability to bind cell proteins is related to the oncogenicity of the HPV type. For example, E6/E7 oncoproteins from HPV $16 / 18$ bind $\mathrm{p} 53 / \mathrm{Rb}$ (respectively) more strongly than HPV 6/11 viral oncoproteins. ${ }^{26}$

It thus becomes increasingly apparent that the detection of integrated viral particles in human cervical epithelium may be important in clinical management of HPV associated cervical neoplasia. This was recently demonstrated in a study estimating the four-year disease-free survival of women with stage $\mathrm{Ib}$ cervical cancer. ${ }^{32}$ Unger $e t$ al found that detection of integrated HPV DNA in the primary tumour was strongly associated with treatment failure. This is the first study highlighting the role of viral integration as a prognostic marker in early cervical cancer. Furthermore, HPV detection and integrated state was not associated with any other clinical variable-for example, histopathology, age at diagnosis, type of treatment, or size of lesion. These authors ${ }^{32}$ used a previously described non-isotopic in situ hybridisation (NISH) assay ${ }^{19}$ to determine the integrated state of $\mathrm{HPV}$ in cervical cancer tissue. The correlation of NISH pattern (punctate/dot/type 2 signal) with HPV integra- tion as determined by Southern blot hybridisation and two-dimensional gel electrophoresis has been verified previously. ${ }^{19}{ }^{33}$ This NISH assay is applicable to archival tissue ${ }^{1718}$ and firmly establishes the location of integrated HPV DNA sequences within tumour cells. This overcomes the technical problems of DNA fragmentation (with inadequate DNA extraction), presence of inhibitors and contamination associated with PCR analysis which has been used to determine the physical state of HPV. ${ }^{23}{ }^{34}$ The NISH assay is also a molecular technique that can be completed within a single working day, permitting easy access to the diagnostic histopathologist for clinical application.

The NISH assay is also capable of distinguishing integrated from episomal viral sequences on morphological grounds. Hence, type 1 (diffuse) represents episomal HPV, type 2 (dot) integrated HPV, and type 3 (mixed) a combination of episomal and integrated HPV. ${ }^{19} 2333$ Following the description of the single dot and multidot nuclear signal patterns in cervical cancer, ${ }^{23}$ it was further proposed that these be designated $2 a$ and $2 b$, respectively. ${ }^{35}$ These single dot signals may be subtle and indistinct, ${ }^{23} 36$ raising the need for extreme caution in the interpretation of NISH signal patterns. Such a cautious approach refers not only to false negativity, where subtle signals may be overlooked by the inexperienced observer, but also to false positivity. The need for a clean background both within the nucleus and on the slide cannot be overemphasised to prevent technical artefact from being misinterpreted as a positive signal. ${ }^{35}$ The converse is also true for the type 1/diffuse intranuclear signal where a subtle hint of "blush" may also be missed. ${ }^{36}$

A further problem is that occasional tumours may demonstrate HPV DNA NISH type 2/dot signals in an isolated focal single cell distribution. ${ }^{18}$ The significance of this pattern has not been elucidated in cervical carcinogenesis, but it is nevertheless plausible to assume that such a detection threshold may well be below that of Southern blot analysis of viral copies/cell. A highly specific and sensitive in situ hybridisation system has been shown to detect 10 viral copies/cell. ${ }^{37}$ In addition, these single type $2 /$ dot signals indicating integrated virus, may also coexist with diffuse staining, varying copy number, episomal virus in cervical cancers. ${ }^{18} 192333$ This therefore raises interesting questions about the sensitivity of Southern analysis in the determination of the physical state of HPV, as viral-host chromosome junction fragments essential for determining isolated integrated virus in a tumour may be masked by a greater viral copy number of episomal virus. ${ }^{35}$

In summary, the role of NISH in the determination of the physical state of HPV in cervical preneoplastic/neoplastic lesions has now been confirmed by three independent laboratories using all available molecular investigative techniques. ${ }^{1923} 3334$ Furthermore, the use of the NISH assay in predicting the prognosis of early cervical cancers has been 
clearly demonstrated. ${ }^{32}$ Studies establishing the role of the NISH assay in predicting the progression of CIN to cervical cancer is awaited. The combined preservation of morphology with the physical state of HPV DNA in cervical cancers permits researchers access to a powerful investigative technique to pursue research into cervical carcinogenesis.

1 Parkin DM, Muir CS. Cancer incidence in five continents Comparability and quality of data. IARC Sci Publ 1992;120:45-173

2 Brinton LA. Epidemiology of cervical cancer-overview. IARC Sci Publ 1992;119:3-23.

3 Herrington CS. HPV and cervical neoplasia. I Classification, virology, pathology, and epidemiology. $f$ Clin Classification, virology, path

4 Bosch FX, Manos MM, Muboz N, Sherman M, Jansen AM, Petro J, et al. Prevalence of HPV in cervical cancer: a worldwide perspective. $\mathcal{F}$ Natl Cancer Inst 1995;87:796802.

5 Lörincz AT, Reid R, Jenson AB, Greenberg MD, Lancaster WD, Kurman RJ. HPV infection of the cervix: relative risk associations of 15 common anogenital types. Obstet Gynecol 1992;79:328-37.

6 Sherman ME, Schiffman MH, Lörincz AT, Manos MM, Scott DR, Kuman RJ, et al. Towards objective quality assurance in cervical cytopathology: correlation of cytopathologic diagnoses with detection of high-risk HPV types. Am F Clin Pathol 1994;102:182-7.

7 Koutsky LA, Holmes KK, Critchlow CW, Stevens CE, Paavonen J, Beckman AM, et al. A cohort study of the risk of CIN grade 2 or 3 in relation to papiliomavirus infection. $N$ Engl $\mathscr{f}$ Med 1992;327:1272-8.

8 Syrjänen KJ. Natural history of genital HPV infections. Papillomavirus Report 1990;1:1-4.

9 Woodman CBJ, Rollason T, Ellis J, Tierney R, Wilson S, Woodman CBJ, Rollason T, Ellis J, Tierney R, Wilson S,
Young L. HPV infection and risk of progression of epitheYoung $\mathrm{L}$. HPV infection and risk of progression of epithe-

10 Campion MJ, McCance DJ, Cuzick J, Singer A. Progressive potential of mild cervical atypia: prospective cytological colposcopic; and virological study. Lancet 1986;ii:237-40.

11 Ho GYF, Burk RD, Klein S, Kadish AS, Chang CJ, Palan P, et al. Persistent genital HPV infection as a risk factor for persistent cervical dysplasia. F Natl Cancer Inst 1995;87: 1365-71.

12 Chua K-L, Hjerpe A. Persistence of HPV infections preceding cervical carcinoma. Cancer 1996;77:12-7.

13 Walboomers JMM, de Roda Husman A-M, Snijders PJF, Stel HV, Risse EKJ, Helmerhorst TJM, et al. HPV in false negative archival cervical smears: implications for screening for cervical cancer. $\mathcal{f}$ Clin Pathol 1995;48:728-32.

14 Herrington CS. Control of HPV replication: implications for squamous neoplasia [editorial]. F Pathol 1996;178:237-8.

15 Lörincz A. Hybrid capture ${ }^{\mathrm{TM}}$ method for detection of HPV DNA in clinical specimens. Papillomavirus Report 1996;7: $1-5$

16 Herrington CS. HPV and cervical neoplasia. II. Interaction of HPV with other factors. 7 Clin Pathol 1995;48:1-6.

17 Cooper K, Herrington CS, Graham AK, Evans MF, McGee JO'D. In situ human papillomavirus (HPV) genotyping of cervical intraepithelial neoplasia in South African and British patients: Evidence for putative HPV integration in vivo. f Clin Pathol 1991;44:400-5.

18 Cooper K, Herrington CS, Graham AK, Evans MF, McGee JO'D. In situ evidence for HPV 16, 18, 33 integration in cervical squamous cell cancer in Britain and South Africa. f Clin Pathol. 1991;44:406-9.
19 Cooper K, Herrington CS, Stickland JE, Evans MF, McGee JO'D. Episomal and integrated human papilloma virus in cervical neoplasia shown by non-isotopic in situ hybridisation. 7 Clin Pathol 1991;44:990-6.

20 Lehn H, Villa LL, Marziona F, Hilgarth M, Hillemans HG, Sauer G. Physical state and biological activity of HPV genomes in precancerous lesions of female genital tract. $\mathcal{F}$ Gen Virol 1988;69:187-96.

21 Diluca D, Monini P, Rotola A, Savioli A, Cassai E. Episomal HPV isolated from a cervical carcinoma presents partial duplication of the early region. Virus Res 1989;14: 49-56.

22 Shirasawa H, Tomita Y, Kubota K, Kasai T, Sekiya S, Takamizawa H, et al. Detection of HPV type 16 DNA and evidence for integration into the cell DNA in cervical dysplasia. f Gen Virol 1986;67:2011-5.

23 Berumen J, Unger ER, Casas L, Figueroa P. Amplification of HPV types 16 and 18 in invasive cervical cancer. Hum Pathol 1995;26:676-81.

24 Kataja V, Syrjänen K, Mantyjarvi R, Vayrynen M, Syrjänen S, Saarikowski S, et al. Prospective follow up of cervical HPV infections: life table analysis of histopathological, cytological and colposcopic data. Eur $\mathcal{f}$ Epidemiol 1989;5: $1-7$.

25 Kataja V, Syrjänen K, Syrjänen S, Mantyjarvi R, Yliskowski M, Saarikowski S, et al. Prospective follow up of genital HPV infections: life table analysis of HPV typing data. Eur f Epidemiol 1990;6:9-14.

26 Vousden KH, Wrede D, Crook T. HPV oncoprotein function: releasing the brakes on cell growth control. Papillomavirus Report 1991;2:1-3.

27 Choo KB, Pan CC, Han SH. Integration of HPV 16 into cellular DNA of cervical carcinomas: preferential deletion of the E2 gene and invariable retention of the long control region and the E6/E7 ORFs. Virology 1987;161:259-61.

28 Schwarz E, Freese UK, Gissmann L, Mayer W, Roggenbuck B, Stremlau A, et al. Structure and transcription of HPV sequences in cervical carcinoma cells [letter]. Nature 1985; 314:111.

29 Matlashewski G, Osborn K, Banks L, Stanley M, Crawford L Transformation of primary human fibroblast cells with HPV type 16 DNA and EJ-ras. Int 7 Cancer 1988;42:232-8.

30 Werness BA, Levine AJ, Howley PM. Association of HPV types 16 and 18 E6 proteins with p53. Science 1990;248: 76-9.

31 Dyson M, Howley PM, Munger K, Harlow E. The HPV 16 E7 oncoprotein is able to bind to the retinoblastoma gene product. Science 1989;243:934-7.

32 Unger ER, Vernon SD, Thoms WW, Nisenbaum R, Spann CO, Horowitz IR, et al. HPV and disease-free survival in FIGO stage Ib cervical cancer. $\mathcal{F}$ Infect Dis 1995;172: 1184-90.

33 Kristiansen E, Jenkins A, Holm R. Coexistence of episomal and integrated HPV 16 DNA in squamous cell carcinoma of the cervix. 7 Clin Pathol 1994;47:253-6.

34 Das BC, Sharma JK, Golapkrishna V, Luthra UK. Analysis by PCR of the physical state of HPV type 16 DNA in cervical preneoplastic and neoplastic lesions. $f$ Gen Virol 1992;73:2327-36.

35 Cooper K. Non-isotopic in situ hybridisation in the detection of integrated HPV $16 / 18$ in cervical cancers [letter]. Hum Pathol 1996;27:745.

36 Cooper K, Herrington CS, Lo E S-F, Evans MF, McGee JO'D. Integration of HPV types 16 and 18 in cervical adenocarcinoma. $f$ Clin Pathol 1992;45:382-4.

37 Herrington CS, Graham AK, McGee JO'D. Interphase cytogenetics III: Increased sensitivity and flexibility of digoxigenin labelled DNA probes for HPV detection in cervical biopsies and cell lines. 7 Clin Pathol 1991;44:33-8.

\section{Molecular Pathology: what's in a name?}

This issue takes us into our third year. Our change of name is not merely cosmetic; our Editorial Board were in accord that the aims and content of the journal would be represented better by the exclusion of the word "clinical" from our title. This does not mean that we do not want to publish material with a clinical emphasis. Our ethos has always been to supplement the content of the fournal of Clinical Pathology with papers and reviews that include pure science which furthers our understanding of disease mechanisms. Molecular Pathology is, therefore, a title which represents accurately the aims and content of this journal.

After only two volumes, Molecular Pathology has over 2000 institutional subscribers worldwide and a combined (with fournal of Clinical Pathology) impact factor of 1.607. Molecular Pathology is indexed in Index Medicus and Current Contents. This is very creditable for so young a publication and indicates that Molecular Pathology is being read and cited by many of our co-workers. We hope that you will continue to support and enjoy $\mathrm{Molecu}$ lar Pathology in the years to come.

With all good wishes for 1997.

Fohn Crocker and David Burnett 